\title{
Ultra-low temperature conservation of Brazilian Pine embryogenic cultures
}

\author{
GRASIELA DEMARCHI ${ }^{1}$, VALDIR M. STEFENON ${ }^{2}$, NEUSA STEINER $^{3}$, \\ FELIPE N. VIEIRA ${ }^{4}$, LIRIO L. DAL VESCO ${ }^{5}$ and MIGUEL P. GUERRA ${ }^{1}$ \\ ${ }^{1}$ Laboratório de Fisiologia do Desenvolvimento e Genética Vegetal, Departamento de Fitotecnia, Centro de Ciências Agrárias, \\ Universidade Federal de Santa Catarina, Rodovia Admar Gonzaga, 1346, Itacorubi, 88034-000 Florianópolis, SC, Brasil \\ ${ }^{2}$ Centro Interdisciplinar de Pesquisas em Biotecnologia, Universidade Federal do Pampa, \\ Campus São Gabriel, Av. Antonio Trilha, 1847, 97300-000 São Gabriel, RS, Brasil \\ ${ }^{3}$ Laboratório de Fisiologia Vegetal, Departamento de Botânica, Centro de Ciências Biológicas, Universidade Federal de Santa \\ Catarina, Rua Engenheiro Agrônomo Andrey Cristian Ferrei, s/n, Trindade, 88040-970 Florianópolis, SC, Brasil \\ ${ }^{4}$ Laboratório de Camarões Marinhos, Departamento de Aquicultura, Centro de Ciências Agrárias, \\ Universidade Federal de Santa Catarina, Rodovia Admar Gonzaga, 1346, Itacorubi, 88034-000 Florianópolis, SC, Brasil \\ ${ }^{5}$ Universidade Federal de Santa Catarina, Campus Curitibanos, Rodovia \\ Ulysses Gaboardi, Km 3, 89520-000 Curitibanos, SC, Brasil
}

Manuscript received on October 29, 2013; accepted for publication on May 5, 2014

\begin{abstract}
This study aimed to establish a cryopreservation protocol for embryogenic cultures of $A$. angustifolia, enabling the ex situ conservation of the species. Embryogenic cultures were established from immature seeds and treated with variations of the cryoprotectant solutions $\mathrm{SuDG}$, SoD and PVS2 prior to immersion in liquid nitrogen. Cell viability was evaluated after 30, 60 and 90 days of re-growth. The highest re-growth without morphological alterations and with normal biochemical composition was obtained with the PVS2 solution with 40 min immersion in ethanol $\left(-20^{\circ} \mathrm{C}\right)$. This procedure opens new horizons for the ex situ conservation of the species genetic.
\end{abstract}

Key words: cryopreservation, ex situ conservation, in vitro culture, plant germplasm conservation.

\section{INTRODUCTION}

Araucaria angustifolia (Bert.) O. Kuntze is the most important native conifer species in Brazil. It is a key stone species in the forest, providing nesting and feeding areas for animals and supplying many plants with shaded environments for their development. At economical level, its wood has several utilities, the resin is source of chemical compounds of industrial interest and the seeds are source of human food and profits to lowincome farmers (Stefenon et al. 2009). Currently,

Correspondence to: Miguel Pedro Guerra

E-mail:mpguerra@cca.ufsc.br this species is classified as highly endangered in the IUCN List of Threatened Species, needing special attention concerning actions towards species conservation. Up to now, the application of biotechnological tools aiming the conservation of the species has basically included the use molecular markers for characterizing genetic diversity and the establishment of somatic embryogenesis cultures.

Due to the recalcitrant nature of the $A$. angustifolia seeds, the maintenance of ex situ seed banks is a challenge and the use of embryogenic cultures seems to be a feasible alternative for the conservation of species germplasm (Stefenon et al. 2009). However, 
problems related to loss of viability and the accumulation of mutations due to long term subculturing could render this process unaffordable (Corredoira et al. 2004). Cryopreservation has been considered an alternative to store large number of genotypes, to avoid loss of embryogenic potential during long-term subculture and to evade possible somaclonal variation (Häggman et al. 1998, Sakai et al. 1991, Verleysen et al. 2004). Ex situ conservation approaches based on cryopreservation have been increasingly employed on plant germplasm conservation (Reed 2001), including conifers (Find et al. 1998, Ford et al. 2000, Touchell et al. 2002, Marthur et al. 2003, von Arnold et al. 2005). The present study intended to establish a cryopreservation protocol for embryogenic cultures of A. angustifolia, aiming to enable long-term storage.

Embryogenic cultures of $A$. angustifolia were established from immature seeds collected from open-pollinated trees, as described by Santos et al. (2001). Immature zygotic embryos were isolated and inoculated in basal medium (Gupta and Pulmann 1991) supplemented with $0.5 \mathrm{~g} \mathrm{~L}^{-1}$ casein hydrolysate, $1 \mathrm{~g} \mathrm{~L}^{-1}$ L-glutamine, $1 \mathrm{~g} \mathrm{~L}^{-1}$ myoinositol, $3 \%$ sucrose, $2 \mu \mathrm{M} 2$,4-diclorophenoxyacetic acid, $0.5 \mu \mathrm{M}$ benzylaminopurine and $0.5 \mu \mathrm{M}$ kinetin $\left(\mathrm{BM}_{2}\right)$. The $\mathrm{BM}_{2}$ medium was autoclaved at $121{ }^{\circ} \mathrm{C}$ for $15 \mathrm{~min}$ and the $\mathrm{pH}$ was adjusted to 5.8 before adding Phytagel ${ }^{\circledR}(0.25 \%)$. Explants were inoculated in Petri dishes containing $25 \mathrm{~mL}$ of $\mathrm{BM}_{2}$ medium and incubated in the dark at $25 \pm 2{ }^{\circ} \mathrm{C}$ for 30 days. Suspension cells were established utilizing $0.25 \mathrm{~g}$ of embryogenic culture inoculated in $120 \mathrm{~mL}$ of liquid $\mathrm{BM}$ medium free of growth regulators $\left(\mathrm{BM}_{0}\right)$ and incubated in the dark on a shaker at $25 \pm 2{ }^{\circ} \mathrm{C}$.

Seventeen cryoprotective treatments were employed (Table I), based on the combination of different osmotic solutions: SuDG [Sucrose: dimetilsulfoxide (DMSO):Glycerol], SoD (Sorbitol:DMSO) and the vitrification solution PVS2 (Sakai et al. 1991). Non-cryopreserved cultures, free of cryoprotective treatments, were used as control.
TABLE I

Composition of the cryoprotective solutions evaluated

\begin{tabular}{|c|c|}
\hline \multicolumn{2}{|r|}{ Control } \\
\hline T0 & $\begin{array}{l}\text { Non-cryopreserved cultures, free of } \\
\text { cryoprotective treatments } \\
\text { SuDG }\end{array}$ \\
\hline $\mathrm{T} 1$ & Sucrose $20 \%+$ DMSO $0 \%+$ Glycerol $20 \%$ \\
\hline $\mathrm{T} 2$ & Sucrose $20 \%+$ DMSO $10 \%+$ Glycerol $20 \%$ \\
\hline $\mathrm{T} 3$ & Sucrose $0 \%+$ DMSO $10 \%+$ Glycerol $20 \%$ \\
\hline $\mathrm{T} 4$ & Sucrose $20 \%+$ DMSO $10 \%+$ Glycerol $0 \%$ \\
\hline $\mathrm{T} 5$ & Sucrose $0 \%+$ DMSO $0 \%+$ Glycerol $20 \%$ \\
\hline T6 & Sucrose $0 \%+$ DMSO $10 \%+$ Glycerol $0 \%$ \\
\hline $\mathrm{T} 7$ & $\begin{array}{c}\text { Sucrose } 10 \%+\text { DMSO } 0 \%+\text { Glycerol } 0 \% \\
\text { SoD }\end{array}$ \\
\hline $\mathrm{T} 8$ & Sorbitol $0.3 \mathrm{M}+$ DMSO $10 \%$ \\
\hline T9 & Sorbitol $0.4 \mathrm{M}+$ DMSO $10 \%$ \\
\hline $\mathrm{T} 10$ & Sorbitol $0.4 \mathrm{M}+$ DMSO $0 \%$ \\
\hline $\mathrm{T} 11$ & Sorbitol $0.3 \mathrm{M}+$ DMSO $0 \%$ \\
\hline $\mathrm{T} 12$ & Sorbitol $0.3 \mathrm{M}+$ DMSO $5 \%$ \\
\hline $\mathrm{T} 13$ & $\begin{array}{l}\text { Sorbitol } 0.4 \mathrm{M}+\text { DMSO } 5 \% \\
\text { PVS2 }\end{array}$ \\
\hline $\mathrm{T} 14$ & $\begin{array}{l}\text { Ethylene glycol } 15 \%+\text { Sucrose } 0.4 \mathrm{M}+\text { Glycerol } \\
30 \%+\text { DMSO } 15 \%\left(40 \text { min in Ethanol }-20^{\circ} \mathrm{C}\right)\end{array}$ \\
\hline $\mathrm{T} 15$ & $\begin{array}{l}\text { Ethylene glycol } 15 \%+\text { Sucrose } 0.4 \mathrm{M}+\text { Glycerol } \\
30 \%+\text { DMSO } 15 \%\left(30 \text { min in Ethanol }-20^{\circ} \mathrm{C}\right)\end{array}$ \\
\hline $\mathrm{T} 16$ & $\begin{array}{l}\text { Ethylene glycol } 15 \%+\text { Sucrose } 0.4 \mathrm{M}+\text { Glycerol } \\
30 \%+\text { DMSO } 15 \%\left(20 \text { min in Ethanol }-20^{\circ} \mathrm{C}\right)\end{array}$ \\
\hline $\mathrm{T} 17$ & $\begin{array}{l}\text { Ethylene glycol } 15 \%+\text { Sucrose } 0.4 \mathrm{M}+\text { Glycerol } \\
30 \%+\text { DMSO } 15 \%\left(10 \text { min in Ethanol }-20^{\circ} \mathrm{C}\right)\end{array}$ \\
\hline
\end{tabular}

For all treatments, $200 \mathrm{mg}$ of embryogenic cultures were inoculated in cryovials containing $\mathrm{BM}_{0}$ medium supplemented with one of the cryoprotective solutions. For solutions SuDG and SoD, samples were held in the medium for 30 min at room temperature and directly immersed in liquid nitrogen (LN). For solution PVS2, the samples were held in the vitrification solution at $0^{\circ} \mathrm{C}$ for $10 \mathrm{~min}$. The cryovials were submerged in ethanol $\left(-20^{\circ} \mathrm{C}\right)$ during $10,20,30$ or $40 \mathrm{~min}$ and subsequently immersed in LN.

After $48 \mathrm{~h}$ in LN, the cryovials were re-warmed for $2 \mathrm{~min}$ in a $40{ }^{\circ} \mathrm{C}$ water bath. These cultures were inoculated in Petri dishes containing $20 \mathrm{~mL}$ of $\mathrm{BM}_{0}$ medium, maintained in darkness at $25 \pm 2{ }^{\circ} \mathrm{C}$ for regrowth and evaluated by measuring their fresh mass independently after 30,60 and 90 days of sub-culture. The experiment was conducted in a 
complete random block, with four repetitions per block for each treatment. Statistical comparisons were made using ANOVA and the SNK test of means separation $(\alpha=5 \%)$.

The viability of the cells after freezing was determined by two cytochemical analyses of the embryogenic cultures: (i) staining with $0.5 \%$ fluorescein diacetate (FDA) and (ii) staining with acetic carmim/Evans-blue.

Aiming to evaluate the patterns of compounds accumulation considering the dynamic of cellular growth after cryopreservation, cells were collected at days 0,16 and 32 of sub-culture in $\mathrm{BM}_{0}$ liquid medium. The contents of proteins and starch were evaluated using three samples: (i) a non-frozen control, (ii) a frozen not re-cultured sample and (iii) a frozen and 60 days re-cultured sample. Embryogenic cultures were cryopreserved using the PVS2 solution with the treatment of $40 \mathrm{~min}$ in ethanol $-20{ }^{\circ} \mathrm{C}$, since this method presented the best outcomes (see below). The content of total proteins was determined from $300 \mathrm{mg}$ of embryogenic cultures following Read and Northcote (1981), using the bovine serum albumin as standard. Extraction of starch was performed following the method of McCready et al. (1950) using the solid discarded fraction of the material employed for protein analysis. The amount of starch was determined through absorbance with a $620 \mathrm{~nm}$ spectrophotometer Shimadzu UV1203, using a standard curve prepared with glucose (0-100 $\mathrm{g} / \mathrm{mL}$, diluted in PCA $30 \%$ ). The experiments were conducted in a complete random block, with three repetitions per block. Statistical comparisons were made using ANOVA and the SNK test ( $\alpha=5 \%)$.

For the cryoprotective solution $\mathrm{SuDG}$, the fresh mass was significantly larger $(p<0.05)$ for the treatments with a combination of two or three cryoprotective compounds in comparison to the control and to treatments using only one cryoprotector (Figure 1). The SoD solution, revealed the best results with the cryoprotective treatments sorbitol $(0.3 \mathrm{M})$ +DMSO (10\%), sorbitol (0.4M)+DMSO (10\%) and sorbitol $(0.3 \mathrm{M})$, presenting fresh mass larger $(p<0.05)$ than the control and the other treatments (Fig. 1). The treatment of cultures with PVS2 solution followed by $40 \mathrm{~min}$ immersion in ethanol resulted in mean values of fresh mass higher $(p<$ 0.05 ) than those resulting from treatments with 10 , 20 or $30 \mathrm{~min}$ immersion and higher than those of the control cultures (Fig. 1). Moreover, in comparison to SuDG and SoD solutions, the PVS2 solution revealed a significantly superior performance on the re-growth after cryopreservation (Fig. 1).

Embryogenic cultures are formed by cells in initial stage of growth and present a high amount of water. During the cryogenic process, this high amount of water results in the formation of ice crystals and consequently cell damage. It has been proposed that the cell dehydration may be promoted by increasing the osmolarity of cryoprotective solutions with sugars, DMSO or glycerol (Wang et al. 2002). These substances also inhibit the cell expansion and reduce the cell and vacuole volumes keeping the integrity of plasma membranes and stabilizing proteins in conditions of dehydration and freezing (Gonzales-Arnao et al. 2008). In our study, the combination of sorbitol+DMSO or sucrose+DMSO+glycerol was very effective in promoting protection against damages during freezing and storage. Similar effects were reported for the cryopreservation of Pinus caribaea, Pinus pinaster and Picea abies embryogenic cultures (Cyr 1999). Among all osmotic solutions, the best re-growth was obtained using the solution PVS2. This solution penetrates in the cytosol preventing the formation of ice crystals within the cell (Turner et al. 2001).

Regardless of the cryoprotective treatment employed, the morphological characteristics of the responsive cells to re-growth revealed normal aspect in comparison to control cultures (Fig. 2 A-C). The cytochemical analysis using the carmim aceticEvans blue staining (Fig. 2 D-F) revealed small isodiametric and low vacuolated embryogenic cells 


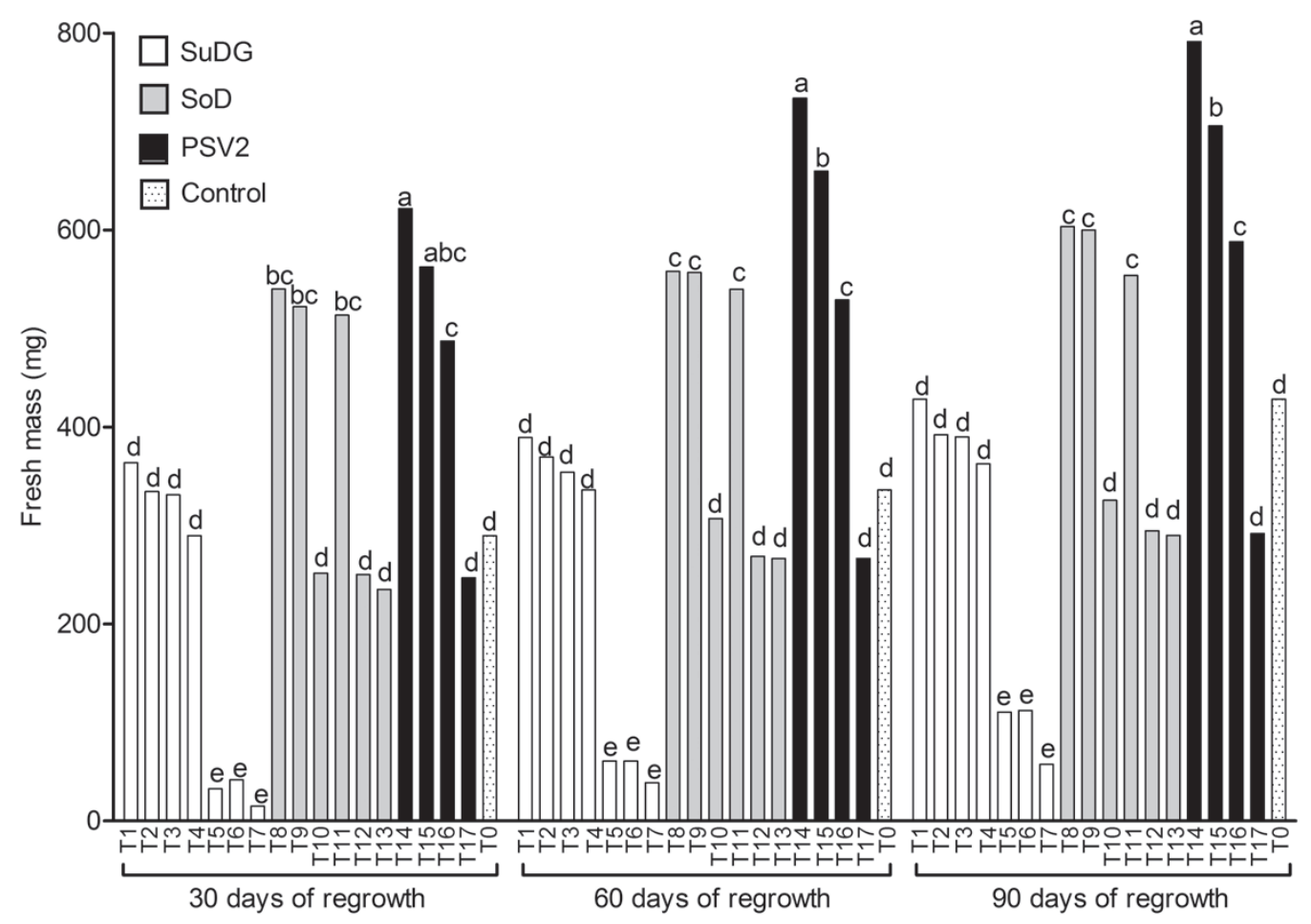

Figure 1 - Fresh mass of the A. angustifolia embryogenic cultures after 30, 60 and 90 days of re-growth in BM medium treated with SuDG, SoD and PVS2 cryoprotectant solutions. Columns with different letters in the same sub-culture (30, 60 and 90 days) are statistically different at 5\% according to SNK test.

with dense cytoplasm and high nucleus-cytoplasm rate. Larger suspensor cells with relatively bigger vacuoles were also observed, in minor frequency. The FDA staining analysis (Fig. 2 G-I) clearly revealed the presence of viable embryogenic cells in the cryopreserved cultures.

It has been suggested that the elimination of non-embryogenic cells from the cultures during the cryogenic storage, brings a beneficial effect on embryogenic capacity of re-growth (Häggman et al. 1998). Embryogenic cells are relatively small, highly cytoplasmic and have small vacuoles, characteristics that improve their resistance capacity to the freezing process (Zoglauer et al. 2002).

The non-frozen cultures revealed higher $(p<$ 0.05 ) amounts of total protein than the frozen ones at 0 and 32 days (Fig. 3), showing a decrease in the protein amount across the dynamic of cellular suspension growth. The frozen not re-cultured samples revealed a slight decrease in protein amount on the $16^{\text {th }}$ day of sub-culture, decreasing considerably on the $32^{\text {nd }}$ day. The frozen re-cultured samples presented a decrease in protein amount on the $16^{\text {th }}$ day and a slight increase on the $32^{\text {nd }}$ day (Fig. 3).

Proteins are important in the cryopreservation process since they stabilize the plasmatic membranes during the osmotic treatment (Hughes and Galau 1989). In the dehydrated cell, membrane proteins are incorporated to a vitreous matrix that preserves its activity and structure. However, proteins are also very sensible to the thawing process and can be denatured (Thierry et al. 1999, Dumet and Benson 2000). Thus, the lower amount of total proteins observed in comparison to non-frozen cultures may be a result of denaturation during the defrosting process.

The amount of starch observed was statistically different $(p<0.05)$ for all treatments (Fig 3$)$. The nonfrozen cells revealed about the same amount of starch for 0 and 16 days of sub-culture with a significant increase on the $32^{\text {nd }}$ day (Fig. 3). The frozen not re- 


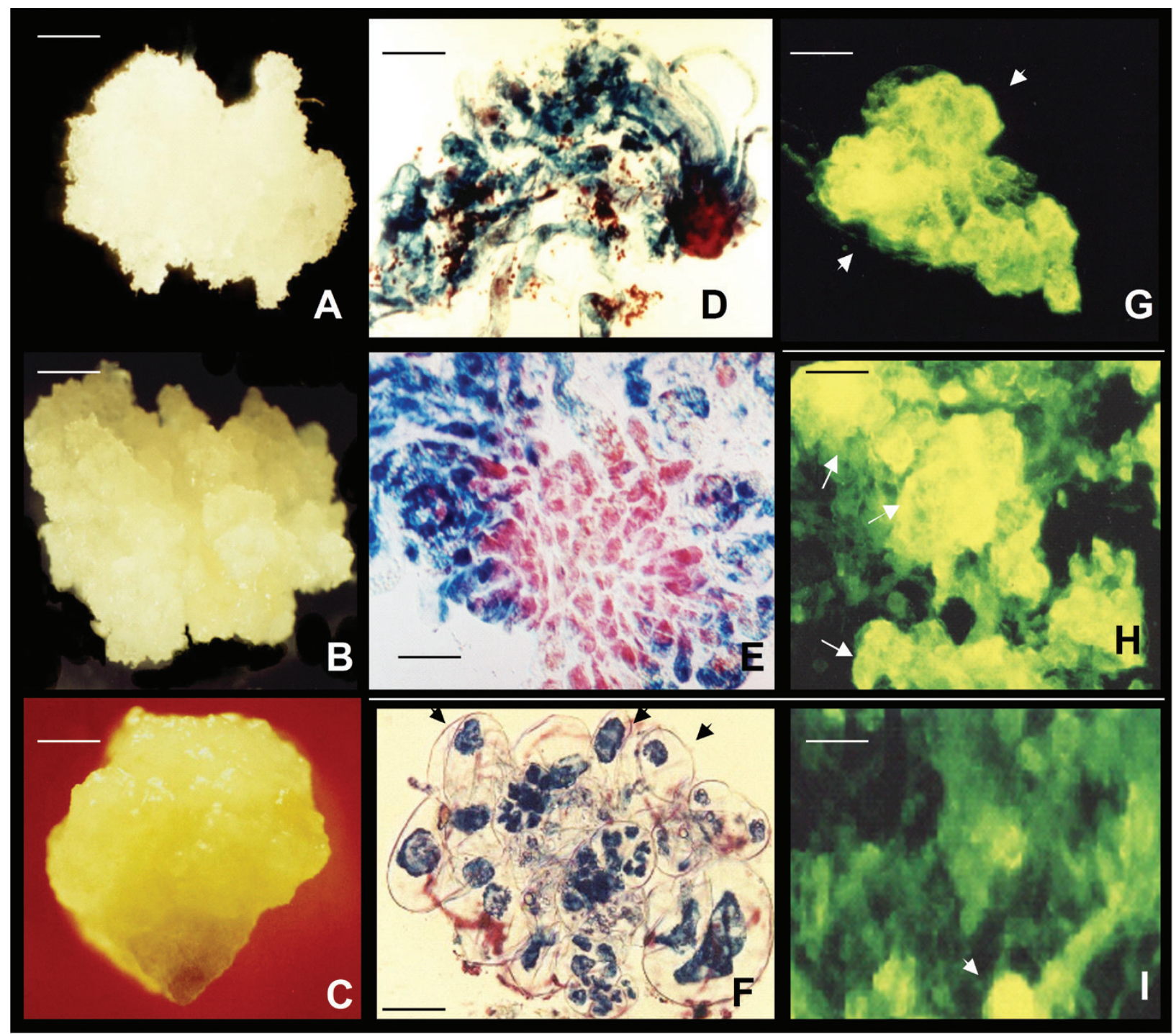

Figure 2 - Cytochemical analysis of the A. angustifolia embryogenic cultures after $48 \mathrm{~h}$ of cryopreservation in liquid nitrogen. A, non-frozen embryogenic culture. Bar $=66.7 \mu \mathrm{m}$. B, embryogenic culture with responsive cells after cryopreservation. Bar $=$ $1.257 \mathrm{~mm}$. C, embryogenic culture without re-growth after 30 days of re-culturing. Bar $=0.587 \mathrm{~mm}$. D, morphological analysis of embryogenic cultures stained with acetic carmim and Evans-blue, evidencing the intact cells of a bipolar somatic pro-embryo. Bar $=33.3 \mu \mathrm{m}$. E, morphological appearance of embryogenic cultures tolerant to cryopreservation, stained with acetic carmim and Evans-blue. Bar $=33.3 \mu \mathrm{m}$. F, morphological appearance of embryogenic cultures not tolerant to cryopreservation, stained with acetic carmim and Evans-blue. Arrows indicate suspensor cells with degraded walls and overflow of cellular content. Bar $=66.7$ $\mu \mathrm{m}$. G, embryogenic culture before freezing, stained with FDA. Bar $=18.84 \mu \mathrm{m}$. H-I, morphological appearance of embryogenic cultures tolerant to cryopreservation, stained with FDA. Arrows indicate viable cells. Bar $=18.84 \mu \mathrm{m}$.

cultured sample revealed the lower content at day 16 , and the highest amount on the $32^{\text {nd }}$ day, while the frozen re-cultured cells presented basically the same amount of starch for 0,16 and 32 days of sub-culture (Fig. 3). For samples of day 32, the high content of starch in the not re-cultured samples evidences the high quantity of sucrose absorbed and converted into starch, while the lower content of starch observed in the frozen re-cultured cells evidences that this compound was metabolized with the cultures re-growth. 


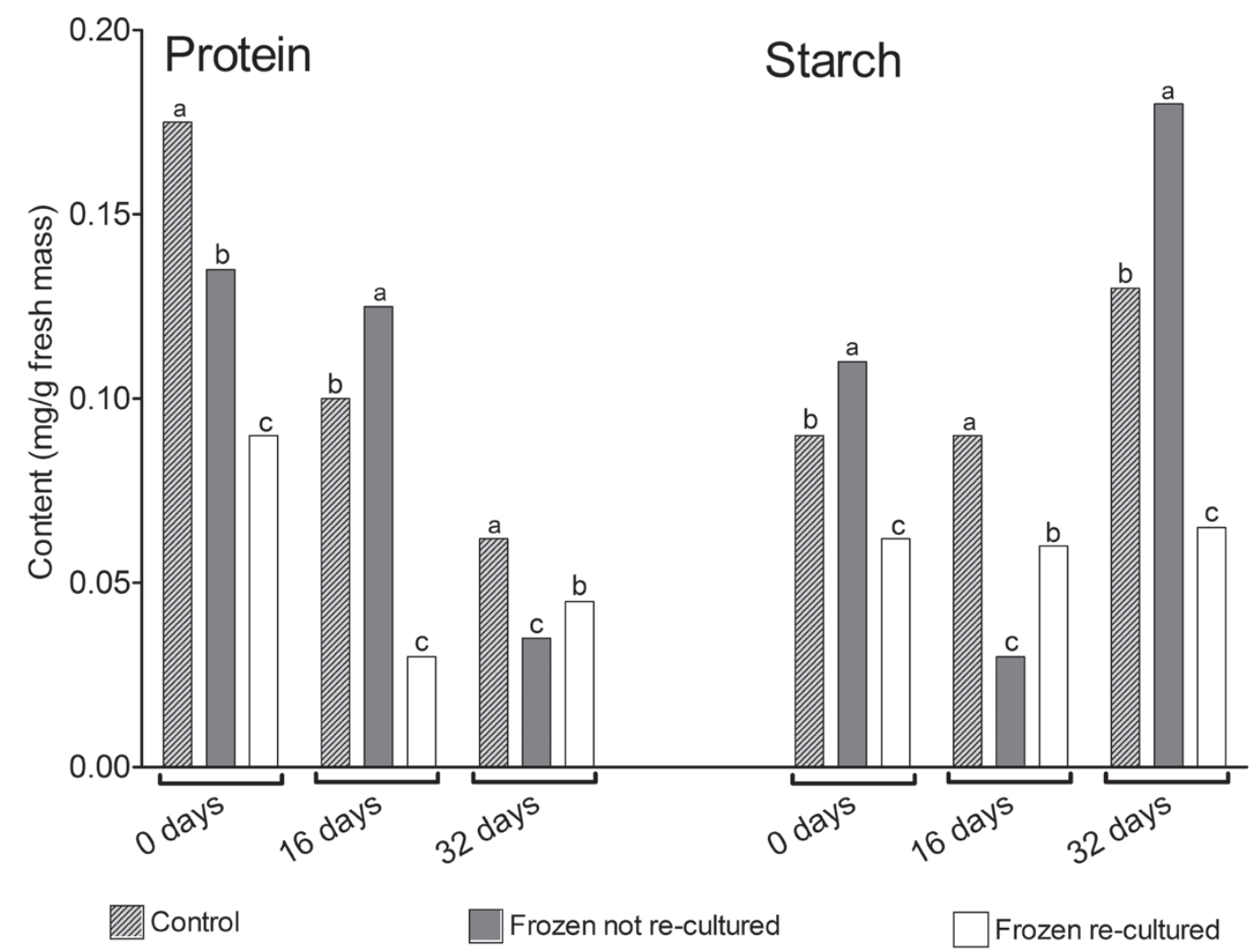

Figure 3 - Content of protein and starch of the A. angustifolia embryogenic cultures, cryopreserved using the PVS2 solution with $40 \mathrm{~min}$ in ethanol $\left(-20^{\circ} \mathrm{C}\right)$. Columns with different letters in the same sub-culture $(0,16$ and 32 days) are statistically different at $5 \%$ according to SNK test.

Our findings show that the vitrification protocol using the PVS2 solution and 40 minutes of immersion in ethanol $-20{ }^{\circ} \mathrm{C}$ is a reliable procedure for the cryopreservation of $A$. angustifolia embryogenic cells. This method may be applied for the conservation of embryogenic cultures of the species, opening new horizons for the ex situ conservation of its genetic resources.

\section{ACKNOWLEDGMENTS}

Authors thank Conselho Nacional de Desenvolvimento Científico e Tecnológico (CNPq), Coordenação de Aperfeiçoamento de Pessoal de Nível Superior (CAPES) and Fundação de Amparo à Pesquisa e Inovação do Estado de Santa Catarina (FAPESC) for grants and fellowships associated to this work.

\section{RESUMO}

Este estudo objetivou estabelecer um protocolo de criopreservação para culturas embriogênicas de $A$. angustifolia, possibilitando a conservação ex situ da espécie. Culturas embriogênicas foram estabelecidas a partir de sementes imaturas e tratadas com variações das soluções crioprotetoras SuDG, SoD e PVS2 antes da imersão em nitrogênio líquido. A viabilidade celular foi avaliada após 30, 60 e 90 dias de recrescimento. $\mathrm{O}$ maior recrescimento sem alterações morfológicas e composição bioquímica normal foi obtido com a solução PVS2 com 40 min de imersão em etanol $\left(-20^{\circ} \mathrm{C}\right)$. Este procedimento abre novos horizontes para a conservação ex situ dos recursos genéticos da espécie.

Palavras-chave: criopreservação, conservação ex situ, cultura in vitro, conservação de germoplasma vegetal. 


\section{REFERENCES}

Corredoira E, SAN-José MC, BALlester A AND Vieitez AM. 2004. Cryopreservation of zygotic embryo axes and somatic embryos of European chestnut. CryoLetters 25: $33-42$.

CYR DR. 1999. Cryopreservation of embryogenic cultures of conifers and its application to clonal forestry. In: JAIN SM, Gupta PK and Newton RJ (Eds), Somatic Embryogenesis in Woody plants, vol 4, Netherlands: Klumer Academic Publishers, p. 239-261.

DUMET D AND BENSON EE. 2000. The use of physical and biochemical studies to elucidate and reduce cryopreservation-induced damage in hydrated/desiccated plant germplasm. In: ENGELMANN F AND TAKAGI H (Eds), Cryopreservation of Tropical Germplasm. Current Research Progress and Application, Rome: Japan International Research Center for Agricultural Sciences/ International Plant Genetic Resources Institute, p. 103-108.

FIND JI, KRISTENSEN MMH, NøRGAARD JV AND KROGSTRUP P. 1998. Effect of culture period and cell density on regrowth following cryopreservation of embryogenic suspension cultures of Norway Spruce and Sitka spruce. Plant Cell Tiss Organ Cult 53: 27-33.

Ford CS, Jones NB AND Staden J. 2000. Cryopreservation and plant regeneration from somatic embryos of Pinus patula. Plant Cell Rep 19: 610-615.

GONZALEZ-ARNAO MT, PANTA A, ROCA WR, Escobar RH AND ENGELMANN F. 2008. Development and large scale application of cryopreservation techniques for shoot and somatic embryo cultures of tropical crops. Plant Cell Tiss Organ Cult 92: 1-13.

GuPta PK AND Pullman GS. 1991. Method for reproducing coniferous plants by somatic embryogenesis using abscisic acid and osmotic potential variation, US patent $5,036,007$.

HÄGGMAN HM, RYYNÄNEN LA, ARONEN TS AND KRAJNAKOVA J. 1998. Cryopreservation of embryogenic cultures of Scots pine. Plant Cell Tiss Organ Cult 54: 45-53.

Hughes DW and GalaU GA. 1989. Temporally modular gene expression during cotyledon development. Gene Devel 3: 358-369.

Mathur G, Alkutkar VA AND NAdgauda RS. 2003. Cryopreservation of embryogenic culture of Pinus roxburghii. Biol Plantarum 46: 205-210.

MCCREAdy RM, GugGOlz J, Silveira V AND OWENS HS. 1950. Determination of starch and amyloses in vegetables. Anal Biochem 22: 1156-1158.
READ SM AND NORTHCOTE DH. 1981. Minimization of variation in the response to different proteins of the coomassie blue $\mathrm{G}$ dye-biding assay for protein. Anal Biochem 116: 53-64.

REED BM. 2001. Implementing cryogenic storage of clonally propagated plants. CryoLetters 22: 97-104.

SAKAI A, KoBAyASH S AND OIYAMA I. 1991. Survival by vitrification of nucellar cells of navel orange (Citrus cinensis Osb. Var. brasiliensis Tanaka) cooled to $-196^{\circ} \mathrm{C}$. J Plant Phys 137: 465-470.

SANTos ALW, SiLVEIRA V, SteInER N, Vidor M AND GUERRA MP. 2001. Somatic Embryogenesis in Parana Pine (Araucaria angustifolia (Bert.) O. Kuntze). Braz Arch Biol Tech 45: 97-106.

Stefenon VM, Steiner N, Guerra MP AND NodAri RO. 2009. Towards the conservation of Araucaria angustifolia genetic resources: genetic diversity, past climatic dynamics and anthropogenic interventions. Biodivers Conserv 18: 2433-2448.

ThIERRY C, Florin B AND PÉTIARD V. 1999. Changes in protein metabolism during the acquisition of tolerance to cryopreservation of carrot somatic embryos. Plant Physiol Bioch 37: 145-154.

Touchell DH, Chiang VL and Tsai CJ. 2002. Cryopreservation of embryogenic cultures of Picea mariana (black spruce) using vitrification. Plant Cell Rep 21: 118-124.

Turner S, Krauss SL, Bunn E, SEnaratna T, DiXon K, TAN B AND TOUCHELL D. 2001. Genetic fidelity and viability of Anigozanthos viridis following tissue culture, cold storage and cryopreservation. Plant Sci 161: 1099-1106.

Verleysen H, SAmyn G AND VAn Bockstaele E. 2004. Evaluation of Analytical Techniques to Predict Viability after Cryopreservation. Plant Cell Tiss Organ Cult 77: 11-21.

Von ARnold S, BozhKov P, Clapham D, DyachoK J, FILONOVA L, HögBerg K, INGOUf M AND Wiweger M. 2005. Propagation of Norway spruce via somatic embryogenesis. Plant Cell Tiss Organ Cult 81: 323-329.

Wang Q, Gafny R, Sahar N, Sela I, Mawassi M, Tanne E AND PERL A. 2002. Cryopreservation of grapevine (Vitis vinifera L.) embryogenic cell suspensions by encapsulation-dehydration and subsequent plant regeneration. Plant Sci 162: 551-558.

Zoglauer K, BehrendT U, RAHMAT A, Ross H AND TARYONO A. 2002. Somatic embryogenesis - the gate to biotechnology in conifers. In: RÜCKER W AND LAIMER H (Eds), Plant Tissue Culture: 100 years since Gottlieb Haberlandt, Vienna, New York: Springer Verlag, p. 1-28. 
